\title{
DNA tagging of blast resistant gene(s) in three Brazilian rice cultivars
}

\author{
S.S. Sandhu ${ }^{1}$, Carlos Colombo ${ }^{2}$, Cândido R. Bastos ${ }^{3}$ and Walter J. Siqueira ${ }^{2}$ \\ ${ }^{1}$ Department of Biological Sciences, R.D. University, Jabalpur, India. \\ ${ }^{2}$ Centro de Genética, Biologia Molecular e Fitoquímica Instituto Agronômico, Campinas, SP, Brazil. \\ ${ }^{3}$ Centro de Graniferas, Instituto Agronômico, Campinas, SP, Brazil.
}

\begin{abstract}
Rice blast is the most important fungal disease of rice and is caused by Pyricularia oryzae Sacc. (Telomorph Magnoporthe grisea Barr.). Seven randomly amplified polymorphic DNA (RAPD) markers OPA5, OPG17, OPG18, OPG19, OPF9, OPF17 and OPF19 showed very clear polymorphism in resistant cultivar lines which differed from susceptible lines. By comparing different susceptible lines, nine DNA amplifications of seven primers $\left(\mathrm{OPA} 5_{1000}\right.$, $\mathrm{OPA}_{1200}, \mathrm{OPG} 17_{700}, \mathrm{OPG} 18_{850}, \mathrm{OPG} 19_{500}, \mathrm{OPG} 1_{600}, \mathrm{OPF} 9_{600}, \mathrm{OPF} 17_{1200}$ and OPF19 ${ }_{600}$ ) were identified as dominant markers for the blast resistant gene in resistant cultivar lines. These loci facilitate the indirect scoring of blast resistant and blast susceptible genotypes. The codomine RAPDs markers will facilitate marker-assisted selection of the blast resistant gene in two blast resistant genotypes of rice (Labelle and Line 11) and will be useful in rice breeding programs.
\end{abstract}

Key words: rice, SCAR, arbitrary primers, Pyricularia oryzae

Received: April 16, 2002; Accepted: May 5, 2003.

\section{Introduction}

Rice blast, an often devastating disease that occurs in most rice-growing areas of the world (Ou, 1985), is the most important fungal rice disease and is caused by the fungus Pyricularia oryzae Sacc. (Telomorph Magnaporthe grisea Barr). Plant resistance to a particular pathogen involves a specific sequence of events (Backer et al., 1997) which are race-specific, being triggered by corresponding host resistance $(R)$ genes and pathogen avirulance $(A V R)$ genes. Resistance mechanisms operate in all plants, and several $R$ genes from monocotyledons and dicotyledons have been isolated which reveal structural similarities in their translated proteins (Backer et al., 1997).

The use of resistant cultivars is the most economically viable and effective way of controlling rice blast (Ou, 1985), but the useful life span of many cultivars is only a few years in disease conducive environments (Lee and Cho, 1990; Kiyosawa, 1982) because of the breakdown of resistance in the face of the high $P$. oryzae pathogenic variability (Ou, 1997; Bonman et al., 1986) and the breeding of cultivars with more durable resistance has become a priority in rice improvement programs.

Resistance is considered durable when it remains effective in a cultivar despite wide spread cultivation in an environment favoring the disease. Durable resistance may

Sendo correspondence to C. Colombo. E-mail: ccolombo@iac.sp. gov.br be controlled by a single gene, multiple genes with cumulative effects or poly genes, and the resistance produced may be either complete or incomplete (partial). Several rice cultivars with durable blast resistance have been identified (Lee et al., 1989; Bonman and Mackill, 1988), and some up land cultivars such as the traditional African cultivars "Moroberekan" and "OS6" have been cultivated for many years in large areas of West Africa without high losses from blast (Notteghem, 1985; Bonman and Mackill, 1988). These plants have been used as resistance donors in breeding programs. Major resistance genes have been successfully used for developing blast resistance cultivars (Khus, 1989) and several dominant resistance genes have been identified which confer complete blast resistance (Kiyosawa, 1981).

Major gene resistance can be deployed either to prevent the blast fungus from easily adapting or to minimize selection pressure on the blast pathogen (Bonman et al., 1992). These objectives can be accomplished by pyramiding conventional blast resistance genes to generate cultivars with durable blast resistance, but phenotypic selection cannot be used to pyramid resistance because the presence of one major gene obscures the effect of other genes. Molecular markers linked to major blast resistance genes offer a powerful tool for marker-aided indirect selection of resistance loci in gene-pyramiding strategies.

Random amplified polymorphic DNA (RAPD) and Restriction fragment length polymorphism (RFLP) have 
been used to construct genetic maps and for the molecular tagging of various agronomic traits in various crop species (O’Brien, 1990; Williams et al., 1993) and a number of blast resistance genes have been mapped relative to tightly linked RAPD and RFLP markers (Naqvi et al., 1995; Naqvi and Chattoo, 1996), but the usefulness of RAPD and RFLP markers in breeding by indirect selection is not well documented (Naqvi and Chattoo, 1996). In this paper, we report that RAPD and sequence characterized amplified region (SCAR) based markers for blast disease in rice differ from cultivar to cultivar of the plant and race to race of pathogen. New RAPD markers for blast resistance in Brazilian rice cultivars which can be used in rice breeding programs are also reported.

\section{Materials and Methods}

\section{Fungal Inoculation, Rice varieties and segregating populations}

Pyricularia oryzae Sacc. was Isolated at the Instituto Agronômico (IAC, Campinas, São Paulo, Brazil) and the inoculum applied by the spray method (Bonman et al., 1986). Disease evaluation was also performed according to Bonman et al. (1986). One very susceptible rice line (line 165) and two resistant lines (line 11 and Labelle) were selected for molecular analysis. These lines are continuously maintained in green houses at IAC and checked from time to time for resistance and susceptibility to $P$. oryzae.

\section{DNA isolation and amplification}

For DNA isolation, fresh leaves ( $2 \mathrm{~g}$ ) were ground in liquid nitrogen and $300-400 \mathrm{mg}$ of ground tissue transferred to polypropylene centrifuge tubes containing $15 \mathrm{~mL}$ of $\mathrm{pH} 8.0$ extraction buffer $(0.1 \mathrm{M}$ Tris $\mathrm{HCl}, 1.25 \mathrm{M} \mathrm{NaCl}$, 0.02 M EDTA), 2\% mixed alkyltrimethylammonium bromide (MATAB) and $1 \% \beta$-mercapto-ethanol. The mixture was slowly stirred for $90 \mathrm{~min}$ at $65^{\circ} \mathrm{C}$ and an equal volume of 24:1 chloroform:isoamylalcohol added twice. The mixture was centrifuged at $10,000 \mathrm{~g}$ for $10 \mathrm{~min}$ and the supernatant transferred to a clean plastic tube containing $100 \mu \mathrm{L}$ of a $10 \mathrm{mg} / \mathrm{mL}$ RNAse solution and incubated at $37{ }^{\circ} \mathrm{C}$ for 30 min after which DNA pellets were obtain by adding 0.8 volumes of isopropanol. After washing with $70 \%$ ethanol, the DNA pellets were vacuum dried and dissolved in $200 \mu \mathrm{L}$ of $\mathrm{pH} 8.0 \mathrm{TE}$ buffer $(10 \mathrm{mM}$ Tris- $\mathrm{HCl}, 1 \mathrm{mM}$ EDTA) and the quality and concentration of DNA fragments evaluated by electrophoresis in $0.8 \%$ agarose gels. This process was repeated for each of the three rice lines.

\section{PCR conditions}

PCR was carried out in a $25 \mu \mathrm{L}$ reaction mixture containing $10 \mathrm{mM}$ Tris- $\mathrm{HCl}, \mathrm{pH} 8.3,50 \mathrm{mM} \mathrm{KCl}, 1.5 \mathrm{mM}$ $\mathrm{MgCl}_{2}, 0.001$ gelatine, $10 \mathrm{ng}$ template DNA, $1.0 \mu \mathrm{M}$ primer, $100 \mu \mathrm{M}$ of each dNTP and 1 unit of Taq polymerase. The DNA was amplified in a PCT-100 thermocycler (M.J. Research, EUA) at $95^{\circ} \mathrm{C}$ for $4 \mathrm{~min}$ followed by 45 cy- cles of $1 \mathrm{~min}$ at $95^{\circ} \mathrm{C}, 1 \mathrm{~min}$ at $35^{\circ} \mathrm{C}, 2 \mathrm{~min}$ at $72^{\circ} \mathrm{C}$ and a final stage of $7 \mathrm{~min}$ at $72^{\circ} \mathrm{C}$. The mixtures were maintained at $4{ }^{\circ} \mathrm{C}$ prior to analysis. For electrophoretic analysis $2.5 \mu \mathrm{L}$ of $0.5 \%$ 1:2:1 bromophenol:blue:glycerol buffer was added and the amplification products loaded onto $1.2 \%$ agarose gel in 1x TAE electrophoresis buffer. The gels were stained with ethidium bromide and photographed and analyzed using a Pharmacia Biotech gel documentation system. About 100 primers (Operon Technology, USA) OPA 1-20, OPF 1-20, OPJ 1-20, OPG 1-20 and OPK 1-20 were tested for polymorphism in the three rice cultivars lines.

\section{Primers for SCAR amplification and analysis}

Six pairs of oligonucleotides (20 pairs of bases both forward and reverse) were designed from the RAPD/SCAR markers for use in SCAR amplification (Table 1) of genomic DNA, which was performed in a standard PCR reaction using $100 \mathrm{ng}$ genomic DNA and 35 cycles of $1 \mathrm{~min}$ at $94{ }^{\circ} \mathrm{C}, 1 \mathrm{~min}$ at $58^{\circ} \mathrm{C}$ and $2 \mathrm{~min}$ at $72{ }^{\circ} \mathrm{C}$. The amplified products were separated by electrophoresis in $1.2 \%$ agarose gels which were stained with ethidium bromide and photographed and analyzed using a Pharmatia gel documentation system.

\section{Results and Discussion}

\section{Primer screening}

Sixty-five of the 100 primers tested, were selected as suitable primers on the basis of good DNA amplification and more than three sharp electrophoretic bands. Variation in the three rice lines was observed with 27 of the 65 primers selected. Twelve of the 27 primers tested, (OPA5, OPF5, OPF9, OPF17, OPF19, OPJ1, OPJ7, OPJ9, OPJ16, OPJ17, OPG19 and OPK12) showed amplification variation in resistant and susceptible varieties and hence were selected for detailed RAPD analysis. When these 12 primers were tested for RAPD analysis in other rice cultivars (including the three original lines), the primers OPA5, OPG17, OPG18, OPG19, OPF9, OPF17 and OPF19 (Figure 1) showed very clear polymorphism in resistant lines but not in susceptible lines, and were thus considered to be suitable RAPD markers.

\section{RAPD analysis}

Comparing resistant and susceptible lines, 9 fragments (OPA5 $5_{1000}, \quad \mathrm{OPA} 5_{1200}, \quad \mathrm{OPF} 9_{600}, \quad \mathrm{OPF} 17_{1200}$, OPF19 $9_{600}, \mathrm{OPG} 17_{700}, \mathrm{OPG} 18_{850}, \mathrm{OPG} 19_{500}$ and OPG19 $9_{600}$ ) were identified as markers potentialy related to the blast resistance gene in the resistant cultivar lines that will be confirmed through a genetic segregation study.

\section{Verification of the established molecular markers of blast resistance for three Brazilian rice cultivars lines}

We tested the amplification of the same fragments obtained by these authors to verify the blast resistance molecular markers established by other investigators (Zhuang et 
al.,1998; Naqvi and Chatto, 1996). The contradictory results are shown in Table 1. In the present study, the molecular marker OPF6 did not give any $2.7 \mathrm{~kb}$ DNA amplification in either resistant lines or susceptible lines as observed by Naqvi and Chatto (1996), suggesting that marker OPF $6_{2700}$ is not a universal molecular RAPD/SCAR marker for blast resistance. The two blast resistance SCAR markers (P265-560 and P286-350) designed by Zhuang et

Table 1 - Nucleotide sequences of SCAR/RAPD markers for a rice-blast resistance gene.

\begin{tabular}{|c|c|c|c|}
\hline RAPD marker & Orientation & SCAR/RAPD Primer sequence & Polymorphisms \\
\hline \multirow[t]{2}{*}{$\mathrm{P} 265-550$} & Forward & 5' CAGCTGTTCAGTCGTTTG 3' & None detected \\
\hline & Reverse 5' CAGCTGTTCATACAAGAAAT 3' & None detected & \\
\hline \multirow[t]{2}{*}{$\mathrm{P} 286-350$} & Forward & 5' GCTCCGCATTAACGGGAAG 3' & None detected \\
\hline & Reverse & 5' AGCCGGCTCCGGAGGTGA 3' & None detected \\
\hline OPF6 & Forward & 5’ GGGAATTCGG 3' & None detected \\
\hline OPH18 & Forward & 5' GAATCGGCCA 3' & None detected \\
\hline OPA5 & Forward & 5’ AGGGGTCTTG 3' & Detected \\
\hline OPG17 & Forward & 5' ACGACCGACA 3' & Detected \\
\hline OPG18 & Forward & 5' GGCTCATGTG 3' & Detected \\
\hline OPG19 & Forward & 5' GTCAGGGCAA 3' & Detected \\
\hline OPK12 & Forward & 5' TGGCCCTCAC 3' & Detected \\
\hline OPF9 & Forward & 5' CCAAGCTTCC 3' & Detected \\
\hline OPF17 & Forward & $5^{\prime}$ AACCCGGGAA 3' & Detected \\
\hline OPF19 & Forward & 5' CCTCTAGACC 3, & Detected \\
\hline
\end{tabular}
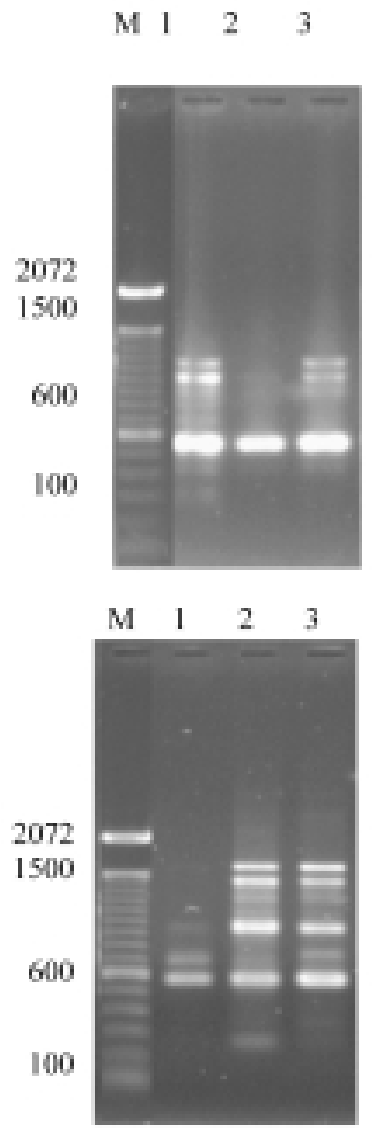
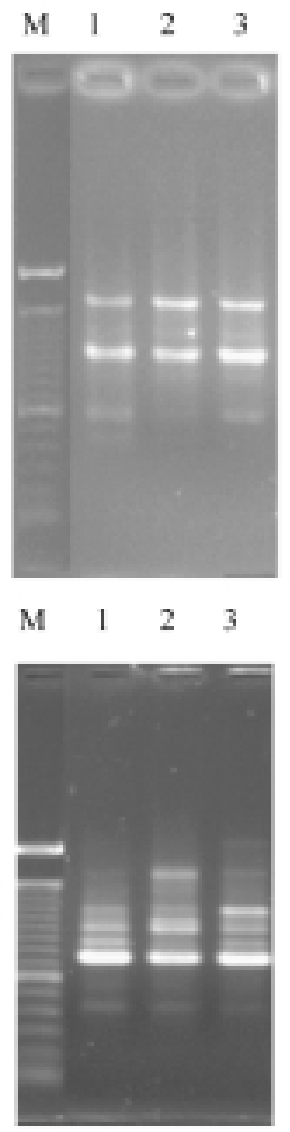
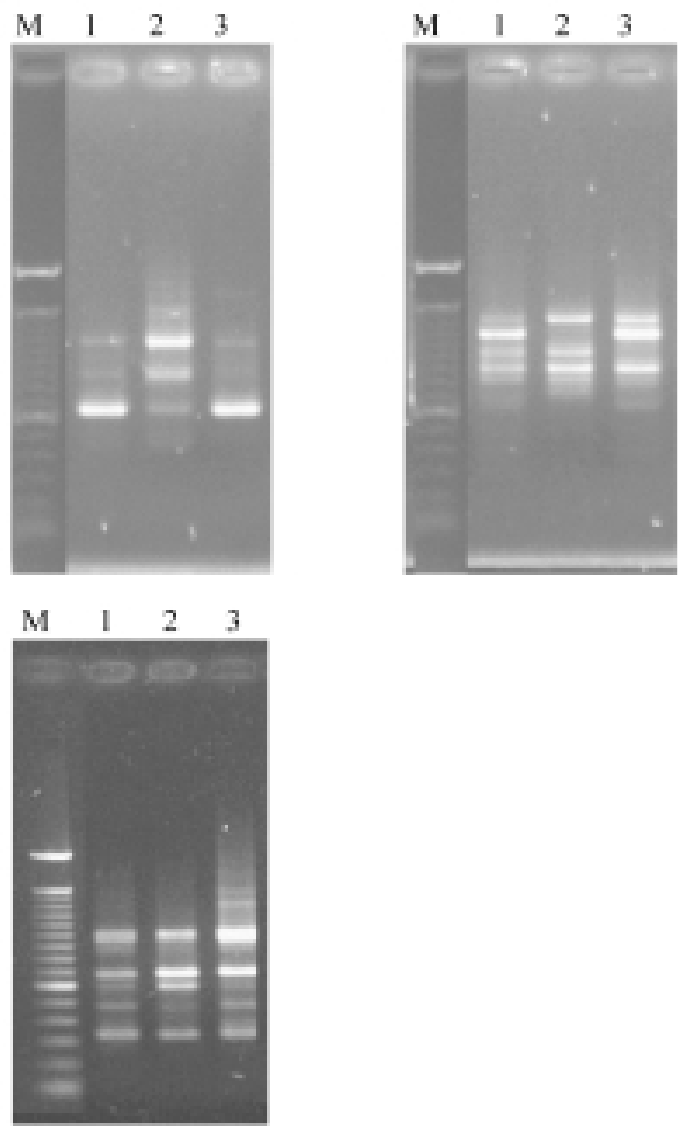

Figure 1 - Ethidium Bromide stained electrophoretic profile of RAPD markers (A $=\mathrm{OPA} 5_{1000}$ and OPA5 $5_{1200}, \mathrm{~B}=\mathrm{OPF} 9_{600}, \mathrm{C}=\mathrm{OPF} 19_{600}, \mathrm{D}=\mathrm{OPF} 17_{1200}$, $\mathrm{E}=\mathrm{OPG} 17_{700}, \mathrm{~F}=\mathrm{OPG} 18_{850}, \mathrm{G}=\mathrm{OPG} 19_{500}$ and $\mathrm{OPG} 19_{600}$ ) for resistant line 11 (sample 1), susceptible line 165 (sample 2) and resistant line "labelle"(sample 3). $\mathrm{M}=100$ base-pair marker. 
al., (1998) were also tested in the current study, but P265560 did not amplify any $560 \mathrm{~kb}$ fragment as reported by Zhuang et al. (1998) for Chinese rice varieties K80R and K79S. However we did find that primer P286-350 could amplify the $350 \mathrm{bp}$ fragment in all the rice lines tested by us, but when examined for polymorphism, as suggested by Zhuang et al. (1998), digestion with Alu1 and Hae III showed that all the three rice lines gave similar digestion patterns (Figure 2) and hence P286-350 cannot differentiate between susceptible and resistant rice lines.

These findings suggest that the SCAR markers designed by Zhuang et al. (1998) and Naqvi and Chatto (1996) are not universal RAPD/SCAR markers for all blast-resistant rice varieties. The availability of codomine RAPD markers for other blast resistance genes would be extremely useful in gene-pyramiding studies and in the detailed mapping of loci for positional cloning projects, as well as being very useful in Brazilian breeding programs for blast-resistant rice.

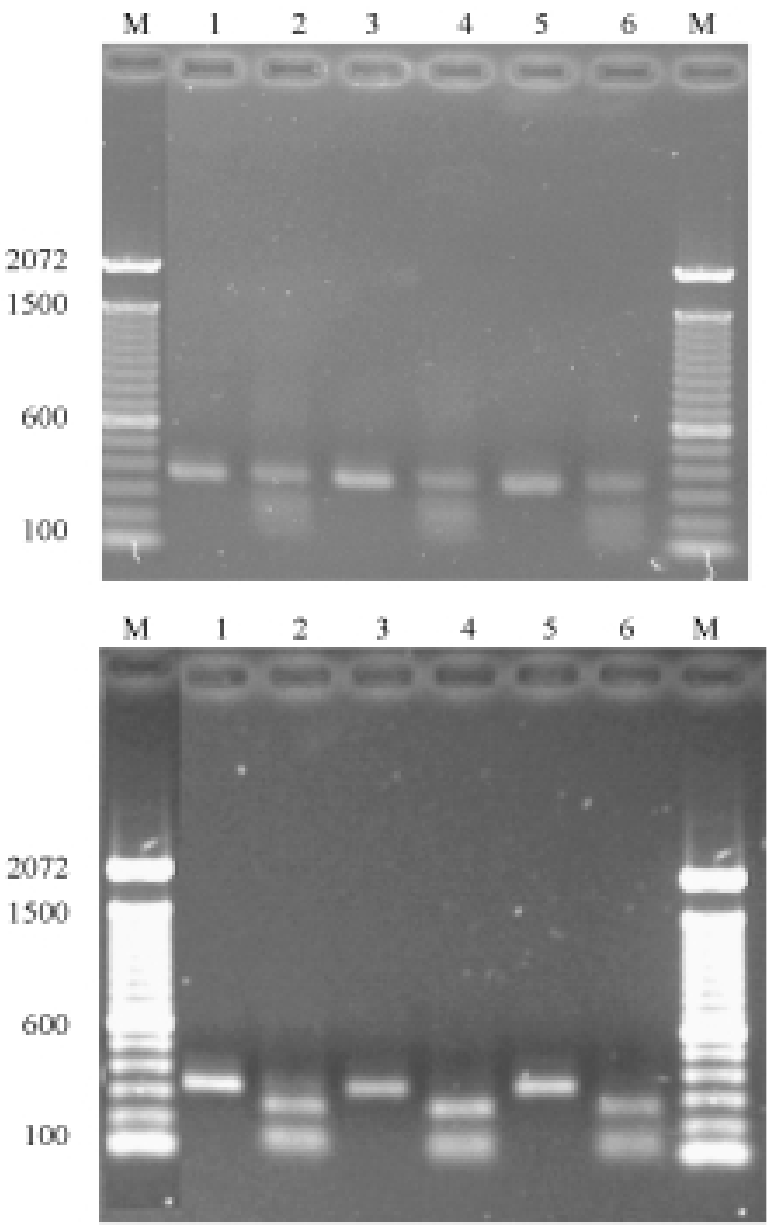

Figure 2 - Ethidium Bromide stained electrophoretic profile of the digested and undigested $350 \mathrm{~Kb}$ SCAR fragment from SCAR marker P286$350=$ resistant line 11 (samples 1 and 2), susceptible line 165 (samples 3 and 4) and resistant line "labelle"(samples 5 and 6). $M=100$ base-pair marker. Samples 1,3 and 5 are from the undigested SCAR fragment while samples 2,4 and 6 were AluI-digested (A) and Hae-digested (B).

\section{Acknowledgments}

S.S. Sandhu thanks CNPq (Brazil) and TWAS (Italy) for financially supporting the visit to IAC, Campinas, Brazil.

\section{References}

Baker B, Zambryski P, Staskawicz B and Dinesh-Kumar SP (1997) Signaling in Plant-Microbe interaction. Science 276:726-733.

Bonman JM, Vergyl de DoisTI and KhinMM (1986) Physiologic specialization of Pyricularia oryzae in the Philippines. Plant Dis 70:767-769.

Bonman JM, KhusGS and Nalson RJ (1992) Breeding rice for resistant to pests. Annu. Rev. Phytopatholo 30:507-528.

Bonman JM and Mackill DJ (1988) Durable resistance to rice blast disease. Oryza. 25:103-110.

Khus GS (1989) Multiple disease and insect resistance for increased yield stability in rice. Progress in irrigated rice research. International Rice research Institute, P.O. Box 933, Manila, The Philippines.

Kiyosawa S (1981) Gene analysis for blast resistance. Oryza 18:196-203.

Kiyosawa S (1982) Genetic and epidamiological modelling of breakdown of plant disease. Annu Rev Phyto 20:93-117.

Lee EJ and ChoSY (1990) Variation in races of rice blast disease and varietal resistance in Korea. Paper presented in the focus on irrigated Rice, 27-31 Aug.1990, Seoul, Korea.

Lee EJ, Zhang Q and Mew TW (1989) Durable resistance in rice disease in irrigated environments, pp 93-110. Progress in irrigated rice research. International Rice research Institute, P.O. Box 933, Manila, The Philippines.

Naqvi NI, Bonman JM, Mackill DJ, Nelson RJ and Chattoo BB (1995) Identification of RAPD markers linked to a major blast rsistance gene in rice. Molecular Breeding 1:341-348.

Naqvi NI. and Chattoo BB (1996)Development of sequence characterized amplified region (SCAR) based indirect selection method for dominant blast-resistance gene in rice. Genome 39:26-30.

Notteghem JL (1985) Definition d'une strategic d'utilisation de la resistance par analysis gnetique des relation hoteparasite Cas du Couple siz-Prricularia oryzae. Agron Trop 40:129-147.

O'Brien SJ (1990) Genetic maps. Cold Spring Harbor Laboratory, Cold Spring Harbor, N.Y.

Ou SH (1997) Breeding rice for resistance to Blast, A critical view, pp 79-137. Proceedings of the rice blast workshop. International Rice Research Institute, P.O. Box 933, Manila, Philippines.

Ou SH (1985) Rice blast. Rice Disease. $2^{\text {nd }}$ ed, The Cambrian News Ltd., U.K, pp 109-201.

Williams JGK, Rafalski JA and Tingey SV (1993) Genetic analysis using RAPD markers. Methods Enzymology. 218:704740.

Yu ZH, Mackill DJ and Bonman JM (1987) Inheritance of registance to blast in some traditional and improved rice cultivars. Phytopathology 77:323-326.

Zhuang JY, Lu J, Qian HR, Lin HX and Zheng KL (1998) Taggning of blast resistance gene(s) to DNA markerassisted selection (MAS) in rice improvement. pp 55-61. Proceedings of final Research Co-ordination Meeting of FAO/IAEA, Austria. IAEA-TECDOC-1010. 